\title{
The imperial treasury: appraisal methodology and regional economic performance in the UK
}

DOI:

10.1080/00343404.2019.1606419

\section{Document Version}

Accepted author manuscript

Link to publication record in Manchester Research Explorer

\section{Citation for published version (APA):}

Sensier, M., \& Coyle, D. (2020). The imperial treasury: appraisal methodology and regional economic performance in the UK. Regional Studies, 54(3), 283-295. https://doi.org/10.1080/00343404.2019.1606419

\section{Published in:}

Regional Studies

\section{Citing this paper}

Please note that where the full-text provided on Manchester Research Explorer is the Author Accepted Manuscript or Proof version this may differ from the final Published version. If citing, it is advised that you check and use the publisher's definitive version.

\section{General rights}

Copyright and moral rights for the publications made accessible in the Research Explorer are retained by the authors and/or other copyright owners and it is a condition of accessing publications that users recognise and abide by the legal requirements associated with these rights.

\section{Takedown policy}

If you believe that this document breaches copyright please refer to the University of Manchester's Takedown Procedures [http://man.ac.uk/04Y6Bo] or contact uml.scholarlycommunications@manchester.ac.uk providing relevant details, so we can investigate your claim.

\section{OPEN ACCESS}




\title{
The Imperial Treasury: appraisal methodology and regional economic performance in the UK
}

\author{
Diane Coyle* \\ (dc700@cam.ac.uk) \\ *Bennett Institute for Public Policy, University of Cambridge, \\ Alison Richard Building, 7 West Road, Cambridge, CB3 9DT, UK \\ and \\ Marianne Sensier ${ }^{\dagger}$ \\ (marianne.sensier@manchester.ac.uk) \\ tEconomics, School of Social Sciences, Arthur Lewis Building, \\ University of Manchester, Oxford Road, Manchester, M13 9PL, \\ UK
}

\section{May 2019}

\begin{abstract}
The disparity between the least and most productive regions in the UK is wide by the standards of many other Organisation for Economic Co-operation and Development (OECD) economies. An important factor is the concentration of public investment around London. The appraisal process for infrastructure investment projects follows the methodology set out in the HM Treasury's Green Book. It is argued that this methodology has reinforced the regional imbalance; that recent changes are unlikely by themselves to redress the London bias in infrastructure; and that infrastructure investments also need to be based on a strategic view about economic development for the whole of the UK.
\end{abstract}

Keywords: Infrastructure; spatial disparities; cost benefit analysis JEL codes: H54, O18, R11 


\section{INTRODUCTION}

The Mayor of Greater Manchester, Andy Burnham, commented in 2017 on his experience as chief secretary to the HM Treasury a decade earlier: "Officials took me through the costbenefit analysis used by the Department for Transport and the Treasury to assess the viability of transport projects. This was almost exclusively an economic test and projects were judged by the economic value they created. In short, projects in parts of the country where the economy was strongest were more likely to score highest. What about areas with higher social need that required better transport to grow their economy? No weighting was given to that, I was told." (Burnham, 2017)

Project appraisals of the kind the then-minister was shown follow the guidance set out in the HM Treasury's Green Book, which has recently been updated in important ways, with the new version published in March 2018 (HM Treasury, 2018). Official appraisal methods have for some time formally allowed cost-benefit analysis (CBA) assessments to consider wider benefits, where there is good evidence available. For example, in 2011, The Green Book was amended to include "valuing non-market impacts" for value, utility, welfare and well-being (HM Treasury, 2011, pp. 57-58). This methodology takes into account social costs and benefits and attempts to quantify non-market impacts of health, educational success, family and community stability and environmental assets. These are welcome extensions.

However, in transport appraisals, the methodology used favours the capital as it includes the 'wider' benefits of agglomeration impacts, dependent development and increases in more productive jobs. This implies that projects in areas that are already the densest, with the highest land values, and the most productive jobs will continue to score higher in appraisals of benefits. Investment in the future is determined by past success, giving rise to a 'Matthew Effect' whereby further infrastructure investment occurs in places that are already successful. ${ }^{1}$ As Merton (1968) observed, this feedback effect means there is a self-fulfilling character to many policy interventions. The present paper discusses the skew delivered by the transport appraisal methodology as set out in The Green Book and Department for Transport guides; and it discusses the flaws in the methodology that mean it is a poor tool for taking a long term view about the economy and, in particular, the spatial aspect of growth. We also highlight the role politics inevitably plays in major investment decisions, as even where projects outside the South East that pass cost-benefit hurdles are much less likely to be approved. A strategic view about regional economic balance in the UK requires political commitment as well as a refined methodological approach.

\footnotetext{
1 Matthew 13 11-12: "For whosoever hath, to him shall be given, and he shall have more abundance."
} 
The paper is structured as follows. The next section describes the data on transport infrastructure spending in the UK, and its regional skew. We then consider the CBA and appraisal methodology used in the UK, and why that may result in an increasing regional skew. We argue that the recent Green Book revisions will not overcome this feature of the appraisal methods, and a new 'Rebalancing Toolkit' (Department for Transport, 2017) intended to supplement the appraisal processes remains unlikely to change the skew. This can change, however, if decisions about significant investments explicitly incorporate a strategic view about economic development for the whole of the UK, as the economic theory underpinning CBA implies should be the case. Rather than only investing in already highly productive places, this would enable public infrastructure investment to reflect the government's strategic view about potential productivity gains - potential that government actions could themselves help realize, given the self-fulfilling character of some policies. The paper concludes by discussing the need for a revised approach to infrastructure investment in the context of both the case for a sustainable industrial strategy to raise national productivity and the political dynamics of English city devolution and the 'left behind' places.

\section{REGIONAL DISPARITIES AND TRANSPORT INFRASTRUCTURE SPENDING IN THE UK}

There is wide regional economic disparity in the UK between productivity per head in London and other English regions along with Scotland, Wales and Northern Ireland. Real productivity for each region is calculated as the Office for National Statistics (ONS) (2018a) estimate of real gross value added (GVA) (in 2016 pounds) divided by the ONS's (2018b) productivity jobs figures. Figure 1 compares real productivity per job filled of each NUTS-1 region less the London amount to show the difference for three separate years: 1998 is the first available year in the series, 2007 is the year that the pre-recession peak was reached for most regions (Sensier and Devine, 2019) and 2017 is the latest available year. This gap has grown over time and even for the South East has doubled in two decades. The share of real GVA earned by London has increased from $19.9 \%$ of the UK total (excluding Extra-Regio) in 1998 to a $24 \%$ share in 2017 , when the share of jobs in the capital has increased from $14.8 \%$ in 1998 to $16.6 \%$ in 2017.

Living standards and productivity are affected by many variables, and there is a large literature on the possible explanations for the UK's regional imbalance; patterns of infrastructure spending are only one possible contributory factor (McCann, 2016). International comparisons of this form of spending are not straightforward. However, noting the importance of infrastructure - both new investment and maintenance - for productivity and well-being, the Organisation for Economic Co-operation and Development (OECD) has observed that the UK has been spending less on infrastructure than other of its member economies for some decades, and also that its perceived quality was lower than in the other G7 countries (Pisu et al 2015). Crescenzi et al (2016) assess the connection between 
regional quality of government and returns to road infrastructure in European Union regions. They find that investment in secondary roads, rather than motorways, improves within-region connectivity, and is correlated with economic growth, particularly where the quality of government is high. They suggest that improvements in the efficiency of public spending, and particularly transport infrastructure investment, will only come about with the development of local institutions (which can identify local needs). There is a consensus that, particularly when it comes to transport, there has been too little infrastructure investment in the UK. ${ }^{2}$ Across the OECD, fiscal devolution is correlated with infrastructure investment where institutional quality is high, (Bartolini et al, 2016). Arbabi et al (2018) present empirical evidence for a link between economic underperformance and inadequate mobility for England and Wales at the intra- and inter-city scale. They suggest that improvements in mobility at the smaller scale within cities initially would help to facilitate much greater improvements at the inter-city scale. Therefore, for example, improving the rolling stock and timetable reliability associated with Northern service throughout Greater Manchester should be the first step before building a high-speed line connecting Liverpool, Manchester, Sheffield and Leeds, as the within city networks need to be able to cope with large amounts of commuters travelling between and within cities.

Figure 1: Difference in Real Productivity from London ( $£$ per filled job; $2016 £$ )

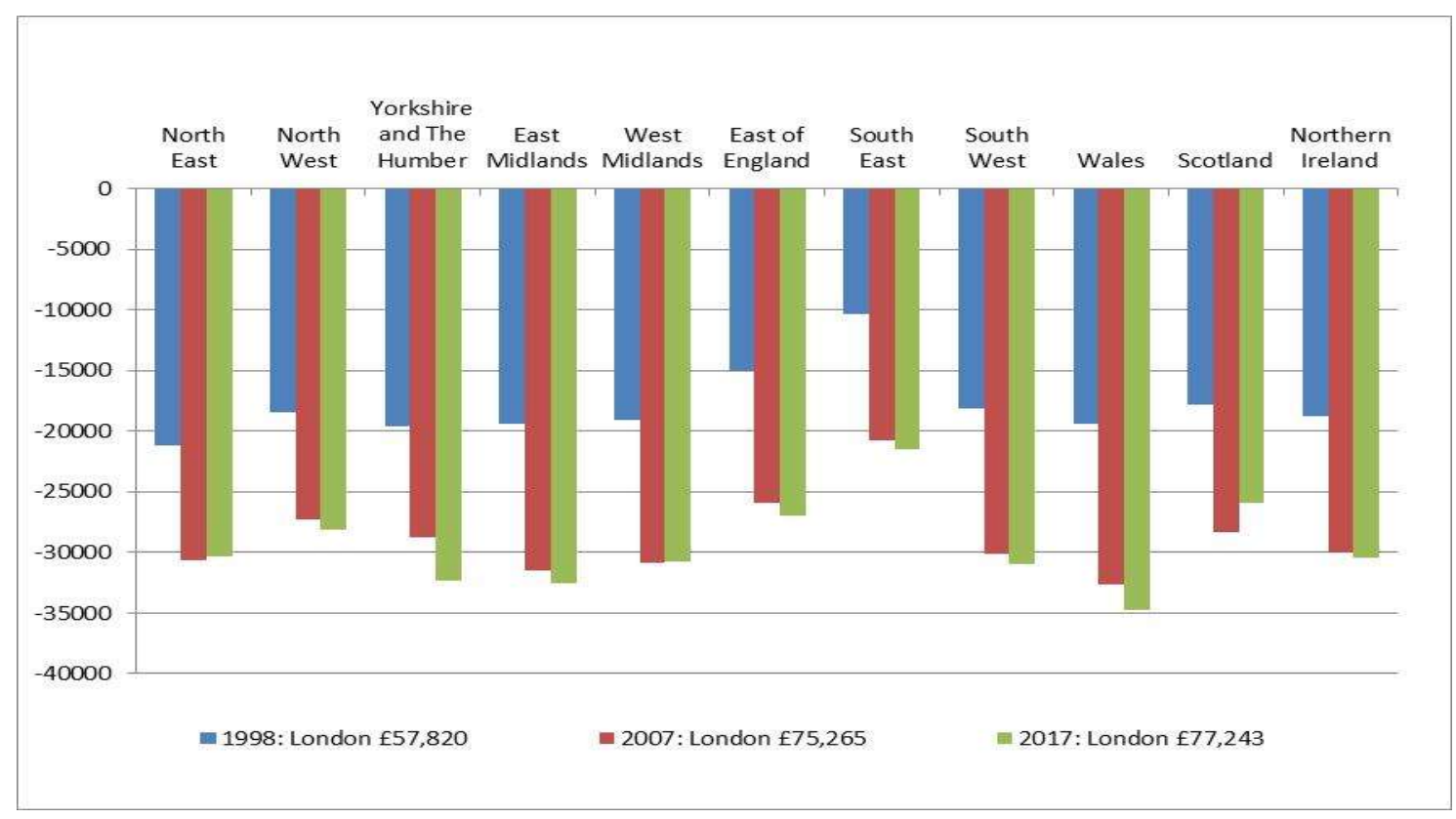

That the level of investment may be unsatisfactory, and that a strategic view is important, was tacitly acknowledged by UK governments with the creation of the National Infrastructure Commission in 2015 and recent modest increases in funding for infrastructure. In 2018, the

2 For example, https://www.weforum.org/reports/the-global-competitiveness-report-2016-2017-1 and $\quad$ https://www.tuc.org.uk/news/uk-languishing-near-bottom-oecd-rankings-investment-vitalinfrastructure 
National Infrastructure Commission published its 30 year horizon strategic assessment. ${ }^{3}$ The November 2017 Budget also announced some spending increases including: expansion of the National Productivity Investment Fund to more than $£ 31$ billion; a $£ 1.7$ billion Transforming Cities Fund for improving transport links within cities; investment of $£ 500$ million in a range of technological initiatives ranging from artificial intelligence, to $5 \mathrm{G}$ and full-fibre broadband; $£ 400$ million investment in a network of electric car charging points - a combination of public and private investment; and $£ 76$ million additional funding for flood and coastal defence schemes over three years. Transport spending has the largest share of funding in the National Infrastructure and Construction Pipeline (NICP) of the HM Treasury and the Infrastructure and Projects Authority (2017). Between 2017 and 2021, this is projected to be $£ 78.5 \mathrm{bn}$ ( $32 \%$ out of a total of $£ 244.7 \mathrm{bn}$ ). This includes central government spending on transport (£60bn), local government (£8bn), private sector (£6bn) and mixed funding (£4.5bn).

The former head of the National Infrastructure Commission and former transport minister Lord Adonis, stated in evidence to a parliamentary committee that the interpretation of cost-benefit ratios had been problematic in past policy decisions. ${ }^{4}$ He said improving rail links east to west in the North of England had been on the agenda since he was Transport Secretary 10 years earlier, arguing that the way cost-benefit ratios are calculated puts too much weight on journey time savings, always favouring London due to its volume of business and commuter travel:5 "All the cost-benefit analysis, and the work that has been done in the Department, doesn't place a high enough premium on significant transformational transport investment in the North. This has been a long running thing. The Government accepts it now which is why it set up Transport for the North."

The skew to the capital in public funding to date is clear, although the extent is contested. The most extreme figures were presented by the think tank Institute for Public Policy Research (IPPR) North: Raikes (2018) calculated that the North West of England is to due receive transport spending of $£ 2,439$ per head, the North East $£ 855$ per head and Yorkshire and Humberside $£ 844$ per head, compared with London's $£ 4,155$ per head (for the period 2017/18 and onwards). The use of these figures to compare the regional investments is strongly challenged in government on the basis that passenger contribution through fares covers much of the cost; and anyway London makes a net contribution in tax revenues to the rest of the UK and therefore needs higher spend per capita to continue to deliver productivity and growth benefiting the whole of the UK. This latter is somewhat circular: if the capital needs

\footnotetext{
${ }^{3}$ See https://www.nic.org.uk/our-work/national-infrastructure-assessment/.

${ }^{4}$ See BEIS select Committee on Industrial Policy: Sector Deals and Productivity on 28/2/18 at: https://www.parliamentlive.tv/Event/Index/380f32b4-5f92-4d9e-8215-ec06a56c4450

${ }^{5}$ The guidance documents distinguish work and commuting travel from leisure travel and also apply different valuations depending on the distance traveled and the mode of transport. Non-work travel is assigned the lowest value, long business trips by rail the highest.
} 
infrastructure to enable it to continue to grow fast and have higher productivity, surely the same reasoning applies to other regions?

HM Treasury publishes an annual record of the Public Expenditure Statistical Analysis (PESA), including a regional allocation of public spending (by central government, local government and public corporations). It also sets out spending by functions. Figure 2 compares the HM Treasury (2017) PESA figures for actual public expenditure on transport over the past four financial years with the projected spending figures published by the Infrastructure Projects Authority (the NICP) and those calculated by IPPR North, (Raikes, 2018). It is important to note the reasons for the differences, including the time periods they cover: PESA and NICP are both for four years whereas the IPPR North figures takes in spending from 2017/18 to beyond 2021/22. The NICP figures are lower than the IPPR North figures because the former's regional analysis counts only central government expenditure and does not include local government spending when provided jointly with central government, (e.g., Crossrail £2.3bn and Thameslink £0.8bn); local government spending, (e.g., London Underground renewal $£ 1.1 \mathrm{bn}$ and line upgrades $£ 1.1 \mathrm{bn}$ ); private sector spending when central or local government is the co-funder (for example: Barking Riverside extension $£ 61 \mathrm{mn}$ ) and any spending beyond 2021/22 (e.g., HS2 and Crossrail $2 £ 31$ billion). In addition, some formerly directly government-funded spend in London is now funded from the capital's retained business rates, so is no longer classified as capital expenditure. This switched funding, which therefore no longer is included in the investment figures, amounts to $£ 240 \mathrm{~m}$ in the current year. By contrast, the IPPR North figures include all of these in its analysis, and hence its figures show a more pronounced skew toward London. However, the PESA figures on actual spend for the past four years also show a strong skew, as do other calculations based on historical spending data (Gibbons, 2017). So indeed does the lived experience of people travelling in and between cities other than the capital. No other UK city has remotely anything like its dense, interconnected public transport network serving London.

In terms of the regional distribution of investment, an inspection of benefit-cost ratios (BCR) of public transport schemes assembled for the Eddington (2006) review and a number of subsequent schemes indicates that London projects or those serving London with relatively low BCRs $(<2)$ have routinely been approved, whereas outside London there is a more mixed picture (Table 1 and Figure 3). (While in theory there is a case for investment in any project with a $B C R>1$ (so that benefits exceed costs), in practice the uncertainties in estimation and the need to prioritise spending mean the de facto threshold is 2.) Some projects with far higher BCRs in the English regions have not gone ahead. This is highly suggestive of political input to the allocation of funds, at least at some aggregated level (Forth 2017). For instance, many economists have challenged the notion that the HS2 project is justified by economic evidence; while the then chair of the Treasury Select Committee said: "HS2 has the weakest economic case of all the projects within the infrastructure programme, 
yet it is being pushed through with the most enthusiasm."6 The scope in Department for Transport appraisal guidance to take into account benefits that cannot easily be expressed in monetary terms can help nudge low BCR but desired projects as nevertheless value for money. The way projects are split, and the timing of revisions to BCR estimates, can also be deployed to justify desired decisions. For instance, the HS2 project has far better BCRs for its northern than its southern phases, and the latter - the first - is more easily justified using a combined BCR for the whole project. ${ }^{7}$ The BCR for the cancelled Midlands rail electrification scheme (on grounds of rising costs) would have been higher if considered as part of an upgrade of the whole route from Bristol to the North of England. On the other hand, the Thameslink upgrade in London did see its BCR revised down (from > 2 initially to 1.24) due to cost escalation, but not until after the work had begun (NAO 2017).

Figure 2: Transport capital spending per head, actual 13/14-16/17 (PESA), projections $17 / 18$ on (NICP and IPPR)

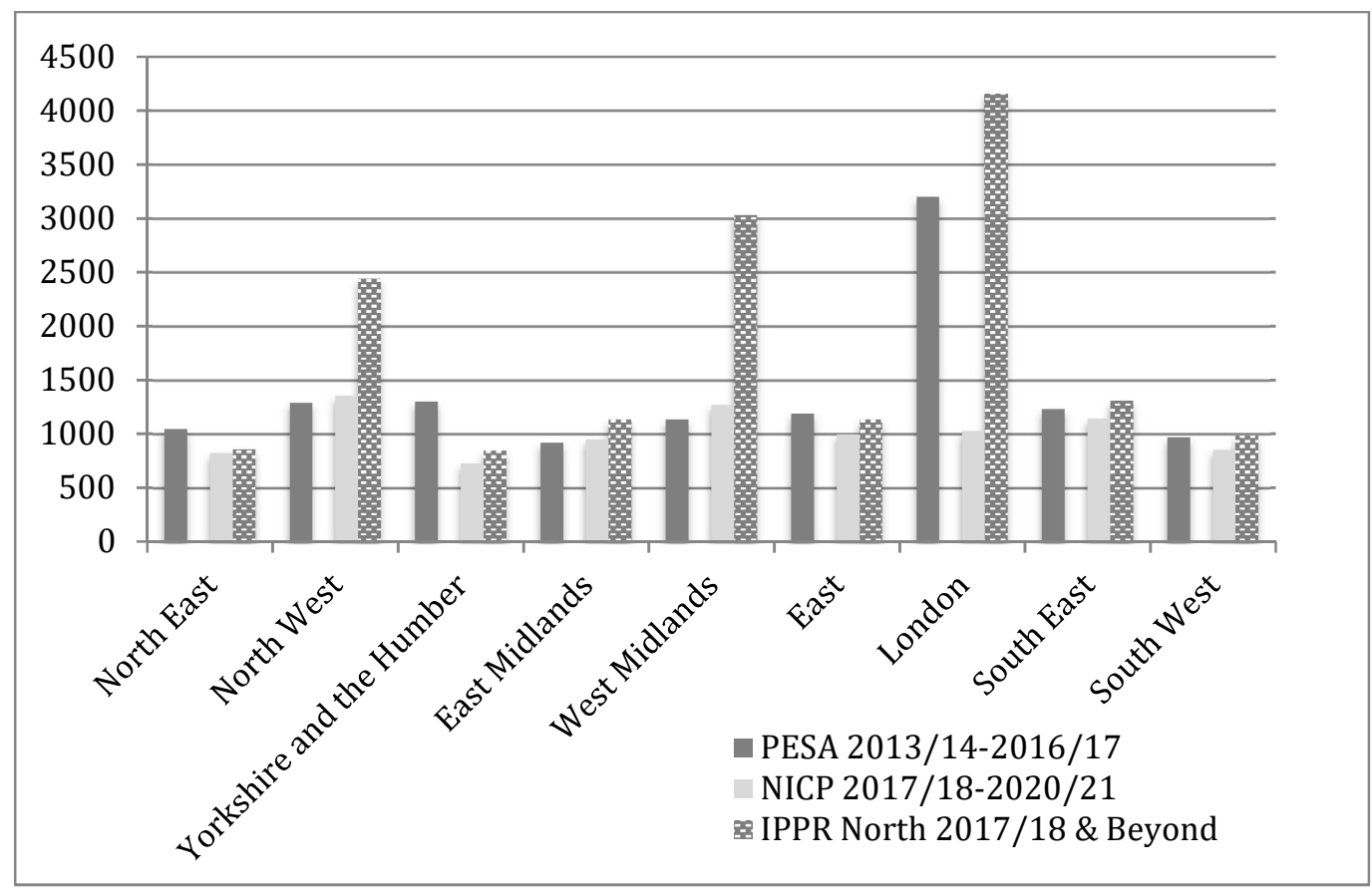

Moreover, as described above, the flexibility to go beyond a 'core' CBA in Department for Transport guidance favours the capital because of its existing density and land and skill premiums. An appraisal process, justified with reference to the need for economic efficiency and delivering productivity growth, may help deliver schemes that are desired for other, noneconomic reasons.

6 See open letter from Andrew Tyrie to Chris Grayling, Transport Minister, here: https://www.parliament.uk/documents/commons-committees/treasury/Correspondence/Chairman-toTransport-Secretary-Airport-Expansion-and-HS2-15092016.pdf

7 See the economic impact of Liverpool HS2 connection line in Figure 6 of Blond et al, (2016). 
Table 1: Public transport schemes, initial benefit-cost ratios (BCRs)

SCHEME

Local public transport schemes

Altrincham Interchange, Greater Manchester

Bletchley Link 2 Public Transport Scheme

Bradford Interchange

Cambridge Guided Bus

Coleshill Multi Model Interchange

Coventry Rapid - Preferred scheme

Doncaster QBC

Greater Bristol Bus Network

Haxby Station

Leeds Supertram

Mansfield Interchange

Newcastle - Eldon Square Concourse

North West Taunton Package

Nottingham Express Transit Extension

South Hampshire Rapid Transit

SPARK Leamington Spa and Warwick

Surrey Pegasus, Guildford Area

Warrington Interchange

Wolverhampton Town Access and Interchange

MyBus, West Yorkshire

\section{Rail schemes}

Crossrail Hybrid Scheme

Thameslink Upgrade

Electrification from London to Cardiff ${ }^{\star}$

Electrification of the Midland mainline*

Electrification from Cardiff to Swansea*

Electrification from Oxenholme to Windermere

Castlefield Corridor (Ordsall Chord), Manchester

Electrification Leeds-Harrogate-York line
BCR

Approved?

$\begin{array}{ll}1.0 & \text { Yes } \\ 3.1 & \text { Yes } \\ 1.0 & \text { No } \\ 2.0 & \text { Yes } \\ 4.8 & \text { Yes } \\ 1.9 & \text { Yes } \\ 1.7 & \text { Yes } \\ 3.2 & \text { Yes } \\ 3.0 & \text { No } \\ 2.3 & \text { No } \\ 4.4 & \text { Yes } \\ 1.2 & \text { Yes } \\ 1.8 & \text { Yes } \\ 2.0 & \text { Yes } \\ 3.6 & \text { No } \\ 2.8 & \text { No } \\ 1.4 & ? \\ 2.0 & \text { Yes } \\ 2.2 & \text { Not yet } \\ 4.0 & \text { Yes }\end{array}$

1.6 to 2.6

Yes

2.1 to 3.0

2.3

4.1 to 13.1

1.4

2.3

2.14 to 2.55

3.61 to 4.27

Yes

Yes

No

No

No

Yes

Not yet

$\begin{array}{ll}2.4 & ? \\ 3.2 & ? \\ 24.5 & ? \\ 1.7 & \text { Yes } \\ 1.1 & \text { Yes } \\ 1.1 & \text { No } \\ 7.4 & \text { Yes } \\ 1.9 & \text { Yes } \\ 1.9 & \text { Yes } \\ 1.9 & \text { Yes } \\ 1.7 & \text { Yes } \\ 11.7 & \text { Yes }\end{array}$

2.5

Schemes from external sources A228 Main Road to Ropers Lane A66 Tees Valley Gateway Study Canal Towpath Local Road
Local Road
Walking/Cycling

DLR London City Airport Light Rail

DLR Woolwich Extension Light Rail

Glasgow Airport Rail System Rail

Heysham to M6 Link Local Road

High Speed Line London-Glasgow Rail ${ }^{\#}$

High Speed Line London-Manchester Rail

High Speed Line London-West Midlands Rail

Jubilee Line Extension

Stansted Surface Access HA

TFL Rail Vision

$\begin{array}{ll}1.3 & ? \\ 2.2 & ? \\ 1.3 & ? \\ 3.6 & \text { Yes } \\ 2.7 & ? \\ 2.6 & \text { No } \\ 2.8 & ? \\ 4.0 & \text { No }\end{array}$

Additional modelling commissioned by Eddington

ECML Additional inter-peak services Leeds -London.

ECML Additional WAGN Peak commuter capacity.

HP-Leeds to Sheffield Highway Improvements

HQ-Leeds Urban Area Highway Improvements

HR-Leeds Urban Area Major Public Transport Investment

HU-Intra Leeds Bus Fare Reduction and Frequency Increase

HV-Leeds to Bradford Improved Highway Connections

HW-Leeds to Bradford Public Transport Improvements

4.0

No 
IF-West Yorkshire Bus Fares Reduction Frequency Increase IJ-S/W Yorkshire Bus Fares Reduction Frequency Increase

IH-S Yorkshire Bus Fares Reduction, Frequency Increase

\section{Others}

Mersey Gateway Bridge

1.55 Yes

Kirkstall Forge, Leeds

Northern Hub Option 1 (£860m)

Northern Hub Option 2 (£560m)

HS2 (full network)

HS2 (phase 2b)

Crossrail 2

4.0

2.1 to 2.7

2.5 to 3.1

2.1 to 2.7
Yes

No

In the National Infrastructure and Construction Pipeline for $16 / 17$ and 17/18

Out of London:

Great Western capacity and electrification

Bromsgrove electrification

In London:

Hull - East Coast Main Line electrification

Gospel Oak to Barking

London Overground asset renewals/enhancements

Notes: * BCRs subsequently revised down; \# Including use of part of existing network from Manchester to Glasgow. The BCR for phase 1 of HS2 was 1.7, compared to the 3.1 for the second phase. BCR cited in each case includes 'wider' effects eg the NATA BCR from Eddington, WebTAG for HS2. For Table sources see Appendix. 
Figure 3: Public transport schemes ranked by initial BCR, approved (dark) and not approved (light). Upper panel - out of London. Lower panel - into London. HS2 connects London with the Midlands/North.

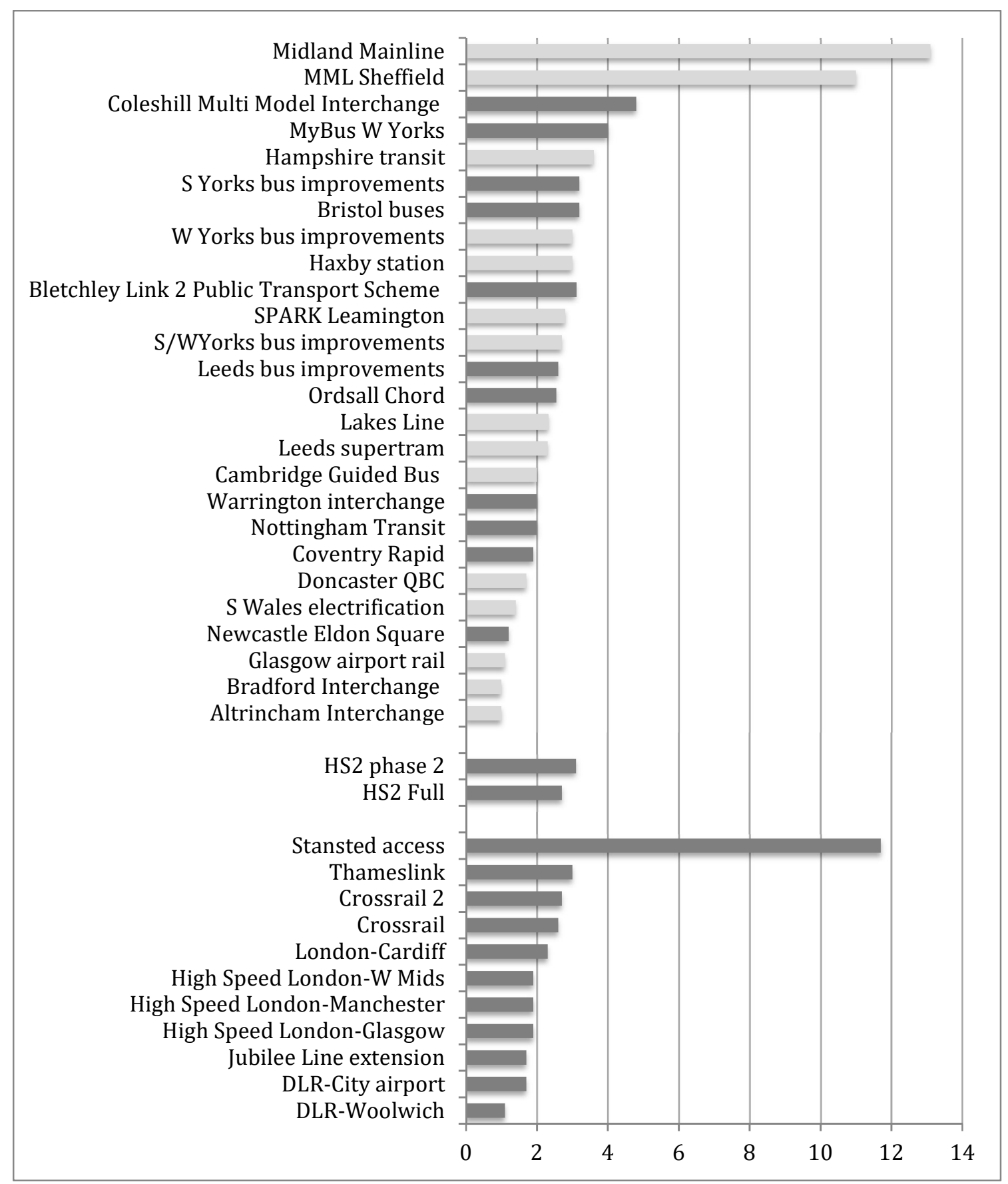




\section{BENEFIT-COST RATIOS (BCRS) OF PUBLIC TRANSPORT INVESTMENT PROPOSALS}

\section{Appraisal methodology in the UK}

The use of CBA and supplementary methodologies for transport investment in the UK has long focused on efficiency and the allocation of scarce resources. HM Treasury insists on a "thorough, long-term and analytically robust approach," (HM Treasury, 2007, Preface). In other words, although the challenges posed by the presence of externalities and 'wider' costs and benefits has been acknowledged for some time, government spending and investment decisions have been - at least in principle - dependent on a quantitative assessment motivated by economic efficiency considerations abstracted from the incorporation of effects not already included in market prices. One specific consequence has been the use, where possible, of prevailing market prices to assign values to future costs and benefits, and also the incorporation of benefits justified by agglomeration economies (Department for Transport, 2018). Graham and Van Dender (2011) have shown that there is a high degree of sensitivity in panel data point estimates for agglomeration due to the highly persistent nature of accessibility measures. Their semiparametric estimates find nonlinear effects with only firms located in London having positive total factor productivity (TFP). Average sized British conurbations are estimated to have no positive relationship between market access and TFP. They say the methodology is unable to distinguish the role of accessibility from other potential explanations for productivity increases. Empirical evidence is needed on the role of different sources of agglomeration and their relative productivity effects to understand the mechanisms that actually drive agglomerations. They suggest, for example, that "Economies associated with labour markets will be affected by the efficiency of commuting trips, knowledge spillovers, the ease of business travel, and externalities of input-output association by provision for freight movement," (p.424).

This economic philosophy was particularly clearly set out in the Eddington (2006) review of transport infrastructure. Although he also noted the importance of trying to incorporate external environmental effects, Eddington forcefully recommended concentrating scarce investment funds on, "Places where transport constraints have significant potential to hold back economic growth," (p6). The report cites the importance of agglomeration effects in driving economic growth, adding: "Transport's contribution to such effects is most significant within large, high productivity urban areas of the UK. London is the most significant example." (p15). This approach means BCRs for London projects are often higher because London is a dense city with high land values and high human capital. The review adds: "In areas without such clear signs [ie rising wages or house prices], it is unlikely that transport is holding back productivity growth." Eddington recommended focusing on transport capacity in and around existing large urban centres, and particularly London, because it was where existing success thanks to agglomeration effects was leading to signs of congestion. 
Although externalities such as getting people off the roads and reducing emissions in train schemes are taken into account in official CBAs, there is no scope for analysis of the limits to agglomeration. For example, the Transport for London (TfL) (2015) report on Crossrail 2 predicts the London population will rise from 8.6 million in 2018 to 10 million by 2030 . The logic is that as London is already more productive than the rest of the UK, anything removing constraints on further agglomeration must be desirable. Yet, it is reasonable to question a methodological approach that gives more weight to mitigating the effects of congestion in the already-crowded capital rather than enhancing the potential productivity and economic development gains elsewhere in the country, even though those places are not manifesting the same market signals of congestion and over-crowding. Hence the cost-benefit case for Crossrail 2, an addition to an already excellent public transport network, looked as attractive in The Green Book procedures as projects upgrading Northern England's rail network, despite the potential for the latter to facilitate the development of a single, dense labour market across the Northern English cities. The Northern rail upgrade was in fact cancelled in 2017 because the Department of Transport had to implement budget cuts. According to the National Audit Office (2018), the CBA analyses of the cancelled projects were all revised to produce lower BCRs as shown in Table 2. The costs were revised up to a significant degree, as they often are when decisions drag on, due to factors including central government delays and procurement failures. The rationale for cancellation also stated that passenger benefits such as enhanced reliability could be delivered in other ways (NAO, 2018). The House of Commons Transport Select Committee (2018) strongly criticized the delays and lack of transparency, and recommended reversing the cancellation decision.

\section{Table 2: Cancelled public transport schemes, revision of Benefit-Cost Ratios}

\section{SCHEME}

Electrification of the Midland mainline

Electrification from Cardiff to Swansea

Electrifcation from Oxenholme to Windermere

\section{$1^{\text {st }}$ BCR}

4.1 to 13.1

0.6

2.3

\section{Final CBR}

0.8

0.3

0.6

\section{Approved?}

No

No

No

Source: National Audit Office (2018).

The general limitations of CBA have been widely aired. Some are inherent in any evidencebased approach to appraisal. The projection of future benefits and costs is uncertain (and as the above example shows liable to big revisions); it is difficult and yet surely essential to include externalities such as environmental impacts; the results are highly sensitive to the choice of discount rate; and general equilibrium effects are not included. There are also considerable implementation issues. For example, Atkins, et al (2017) list four of them:

1. The difficulty of capturing impact, particularly dynamic change in the economy.

2. Unrealistic cost estimates, prone to optimism bias. 
3. Lack of consistency between project assessments. For example, impacts on health, safety and the environment are difficult to monetize and not always included consistently across projects, although this is improving.

4. Poor communication within and outside of Whitehall. CBA results are not always well understood.

Of these, the failure to incorporate dynamic change in the economy is key to the issue of regional skew, as this omission is what traps investment decisions in the past geographic distribution of growth. As the Centre for Urban and Regional Development Studies (CURDS) iBUILD (2018) project final report noted: "The UK government accepts that approaches based solely on static analysis can favour investment and re-investment in places where development has already happened, and relatively higher current market values for wages, housing and land in prosperous places generate higher Benefit-Cost Ratios that often overlooks some of the long-term benefits that infrastructure can bring to different places." (p20). The Green Book of 2013 placed strong emphasis on the use of market prices, as does the new 2018 version, both as the starting point for estimating opportunity costs and in order to value project benefits. We will return below to the new update.

The obverse of the phenomenon has been demonstrated in the case of the 'Beeching Axe' cuts to the UK's rail network in the 1960s. The closures affected little used and unprofitable lines. However, Gibbons et al (2018) show that, even conditioned on the decline of affected areas before the Beeching report, the closures accelerated the population decline, and the proportion of skilled and young workers in the population. They conclude: "An implication of these findings is that rail transport infrastructure plays an important role in shaping the spatial structure of the economy" (p. i).

\section{WHY APPRAISAL METHODOLOGY IS WIDENING REGIONAL GAPS}

CBA is rooted in welfare economics, intended as a quantified, monetary assessment of the total impacts of a project on the lives of those affected over the future lifetime of the investment (Laird et al 2014). However, in policy usage, it is almost always a means of using scarce public funds as effectively as possible to deliver higher productivity and economic growth, in effect as a value for money exercise. 'Wider' effects are accepted as important, but maximizing social welfare is not the true aim of the exercise. Rather, it is a matter of comparing options to boost productivity given scarce funding, while taking into account as far as possible the externalities involved in those options. The extended scope of the consideration of externalities set out in the latest Green Book revision in fact serves to highlight the limitations of the CBA methodology, as it acknowledges some social welfare considerations such as environmental externalities without acknowledging the bigger limitation of applying CBA to significant investments. 
The problem lies in the character of the CBA technique, which is a calculation of the discounted net social benefit under the often-reasonable assumption that the project is marginal. In other words, it assumes that the project being appraised does not change either relevant relative prices or the growth rate of consumption. Dietz and Hepburn (2013) have shown that where the range of net benefits could be a significant share of aggregate consumption, "It is possible for marginal CBA to provide both qualitatively and quantitatively incorrect guidance, by ignoring the impacts of projects on the underlying economic growth path." (p. 62). In other words, CBA is least likely to be valid for projects big enough to affect future economic outcomes, and could be positively misleading. Note that 'big enough' is not simply a matter of scale, as some costly investments (such as improvements to London's already dense public transport network) may be incremental in their specific context, and vice versa. The issue is whether the economic impacts are genuinely marginal.

There has been some recognition of this in the literature. Little and Mirrlees (1974, p. 304) wrote, "We must know where the economy ought to be going ... before we can decide how it ought to start"; but even though their textbook acknowledged that the inter-temporal profile of economic growth would affect project valuations, the authors did not consider how investment projects might themselves alter that inter-temporal output profile. As well as the time profile, the spatial profile can also be altered, with the same reasoning applying.

The error involved in the linear approximation estimating net social benefit is likely to be large when the curvature of the utility function is sufficiently high. ${ }^{8}$ This could be the case when in addition to inter-temporal considerations, there is an aversion to regional inequality (Atkinson, et al 2009). In addition to the inappropriate use of CBA in contexts where non-marginal changes might be expected, such as major infrastructure projects, the UK methodology for transport as already noted reinforces the dynamics of agglomeration, for example, through scoring the economic benefits of related developments, which are more valuable where land values are highest. Sen, Stiglitz and Fitoussi (2009, p. 154) also note the bias in CBA toward the rich, and the need for equity criteria to feature in political decisions before the technocratic cost-benefit techniques are deployed.

Although the new Green Book and Rebalancing Toolkit (Department for Transport, 2017) will lead to some scope for appraisals to give more weight to currently lower productivity places within the current appraisal framework, the emphasis on agglomeration efficiencies means the Matthew Effect will continue to operate, exacerbating the UK's regional imbalance, until investment decisions are set in the framework of a strategic view of economic development, including spatial development. A true social welfare assessment of non-marginal

\footnotetext{
${ }^{8}$ This point refers to the size of the change in utility due to one additional unit of economic output.
} 
infrastructure investments is not possible without knowing where the economy 'ought to be going'; the social welfare function is not a given, but is something on which decision makers can take a view and can affect with major investments.

The Green Book approach to valuing benefits based on current productivity has been strongly criticized by Metz (2016). Pointing to evidence from the National Travel Survey, he notes that daily travel time has stayed roughly constant at about one hour since 1970, which suggests that transport investment does not save time, but rather should be considered in terms of the scope for increases in economic opportunities. In other words, in practice there is little travel time saved from transport projects, undermining the rationale for using time savings as part of the project appraisal method. He concludes: "You cannot build your way out of congestion"(p.19). The Eddington rationale of aiming to ease congestion in high productivity, over-heating places (London) as a means of removing bottlenecks on still more productivity growth there is therefore bound to fail. Metz advocates considering instead that land and property values are often increased by transport projects, and would be a more direct sign of successful economic development in a specific location than the projected value of time saved by travellers. ${ }^{9}$

"An evidence-based approach to transport investment ought not to be contentious. However, the conventional transport economist approach is theory based, not evidence based. Their theory is that the value of transport investments can be estimated by calculating the total time supposedly saved by faster travel. But these time savings are not real. What is real and readily observed are the changes in how the land is used and valued when transport investment makes such land more accessible - which the economists disregard." (P128)

His argument is, therefore, that there are better indicators of potential future productivity. Appraisals should start with a view about where economic development could and should feasibly occur, based on local knowledge of property and land prices, skills needs and industry strengths, and wider societal aims. In other words, the prioritization the methodology claims to deliver, but does not, should be the starting point. Given that framework, which inherently involves a view about the spatial distribution of activity, appraisal methods can then be applied to compare relevant options and sense check assumptions. For instance, an assessment could be run with several possible assumptions about productivity uplift, as a sensitivity test. The need for integration and detailed local knowledge makes it unlikely this kind of appraisal can all be done centrally, although how to cascade the prioritisation of investment from central through regional to local decisions is not clear (Preston, 2012).

\footnotetext{
${ }^{9}$ In theory, when there are perfect markets with no transactions costs, the value of time saved and the increase in property values attributable to time saved would be equal.
} 
There are hints of this approach being taken at sub-national level. Transport for Greater Manchester (TfGM), for example, uses productivity measures alongside CBA. It uses CBA as a 'sifting test' to decide whether an investment should be considered, but BCRs are not used to prioritize. Instead, TfGM prioritises investments based on impact on the GVA for every £1 of investment - a metric developed following direction from Greater Manchester politicians to use the capital budget allocated to support economic growth. "Its 2014 transport strategy and investment plan (GMCA, 2014) provides a clear overview of scheme objectives, monetised benefits, a narrative outlining the case for wider benefits, and a judgement of appraisal robustness" (Stewart, 2013, p. 13). The CBA exercise in this case is a hurdle a project needs to clear, after priorities - in this case, achieving productivity growth - have been established.

\section{WHAT IS CHANGING AND WHY IT IS NOT ENOUGH}

At national level, the new 2018 Green Book takes some welcome steps along this road by taking account in CBA assessments of the productivity impacts of investments, "Where they can be objectively demonstrated," (HM Treasury, 2018, p39), in addition to an extended scope for including non-market environmental, social and wellbeing effects. But it does not go far enough toward a framework that would tilt infrastructure investment toward regions of the UK where it could enable faster productivity growth. In addition, the 2018 revision of The Green Book, along with other recent policy announcements, has acknowledged some of the criticisms of the official appraisal methodology. In addition, following the Industrial Strategy White Paper in November 2017, the Department for Transport (2017) announced the Rebalancing Toolkit. This offers some (non-binding) guidelines for appraisals of investment projects where geographic 'rebalancing' is part of the policy objective. Although it refers to the need for a strategic 'narrative' underpinned by evidence, the evidence suggested includes outcome metrics such as deprivation indices and 'living cost challenges' rather than any meaningful account of the drivers of economic development and productivity growth. A parliamentary report concluded: "It was not immediately clear to us what practical difference the rebalancing toolkit would make in its current form." (Transport Select Committee 2018, $\S 63)$.

The Green Book of 2018 (HM Treasury, 2018) does mark a significant departure from past advice, in highlighting the scope to incorporate dynamic productivity and employment effects. It states:

Productivity effects should be included in the calculation of UK costs and benefits where they can be objectively demonstrated. Productivity effects may arise from movement to more or less productive jobs, changes in the structure of the economy, benefits from dynamic clustering or agglomeration (benefits that arise through close 
location of businesses and/or people), private investment, product market competition or the generation and flow of ideas.

And:

Interventions which increase human capital, job-search activity or provide better access to jobs can have positive labour supply and macroeconomic effects. Provided they can be supported by clear, objective evidence labour supply effects can be included in appraisal. (p. 39)

Setting aside the vexed question of what constitutes 'objective' evidence of future productivity effects, this is a significant recognition of the importance of the previously omitted dynamic effects and the scope for significant investments to make the future in some respects unlike the past. The Green Book revision also includes a far broader scope for the inclusion of 'wider' effects such as environmental and social impacts.

However, it is unlikely to transform the landscape for infrastructure project appraisal. It will be difficult to provide 'clear, objective evidence' of productivity impacts. For instance, it seems reasonably likely that a denser transport network in the North of England could deepen the labour market in the region and enable the kinds of increasing returns spillovers observed in many large urban areas; but it is not obvious what objective evidence of this effect might be in terms of a forward-looking appraisal. There is nothing in the past able to furnish such evidence precisely because the absence of connectivity has made it impossible. Existing appraisal methodology cannot in itself 'rebalance' the economy, especially given the philosophy of more agglomeration economies in one place necessarily implying fewer in another.

\section{DISCUSSION}

The argument we make here - for a genuinely strategic approach to major infrastructure investments - goes against the grain of more than a generation of practice in Whitehall. Among officials there is strong cultural resistance to any approach involving actively seeking to shape the spatial development of the UK economy. For example, the UK's contribution to a recent OECD publication (OECD 2018, p. 21) acknowledges: "The pattern of regional inequality is long-standing but not fixed," and yet proceeds to argue that the productivity and growth performance of lagging regions can only be improved at the expense of the capital. This zero-sum thinking fails to recognize the potentially self-fulfilling dynamics of growth described above.

The 2018 revisions to The Green Book and the Department for Business, Energy and Industrial Strategy (BEIS) (2017) Industrial Strategy White Paper and its subsequent implementation through local industrial strategies perhaps indicate dawning recognition at the 
centre of government that a different spatial distribution of economic activity around the UK is desirable and may be possible. Indeed, it may be politically essential in the context of the politics of devolution in the UK and trends in voting patterns (Rodriguez-Pose, 2018). The Industrial Strategy Commission (2017) said "further and faster devolution" to cities and regions would be essential to raise national productivity levels. The government's Industrial Strategy White Paper accepted this, introducing local industrial strategies and a $£ 1.7 \mathrm{bn}$ fund for improving transport connections within city-regions, among other funding streams; and 'place' is part of the remit of the new Industrial Strategy Council.

Although the use of evidence-based methods in project appraisals is essential to try to use public funds as effectively as possible, the limitations of marginal methods for major projects have long been recognized in theory - but not in practice. One obvious response to this argument is to ask what discipline might be applied instead to enable strategic prioritization of infrastructure projects while guarding against all the well-known problems of major investments (Flyvbjerg 2014). There is an evidence challenge in that it is difficult to identify empirically the contribution of infrastructure investment to productivity growth in different geographies over the long time frames relevant to economic development. In a metaregression analysis of studies for OECD countries, Bom and Ligthart (2014) find the output elasticity of public infrastructure investment is three times higher in the long run than in the short run, and higher for regional and local than for national schemes, but that there is great heterogeneity of outcomes. Donaldson (2018) uses historical data on the build out of the rail network in $19^{\text {th }}$ century British India, finding large welfare gains from access to rail transport, increased regional and inter-regional trade, and decreased trade costs and inter-regional price differences. Crescenzi et al (2016) conclude that the American Recovery and Reinvestment Act of 2009 , providing US $\$ 48.1 \mathrm{bn}$ largely for grants to state and local government for capital expenditure on transport projects, stimulated a large short term increase in gross domestic product (GDP) and employment, which was perhaps not surprising in the business cycle context. In a survey of the impact of transport on regional development, the OECD (2002, p. 11) concluded: "There is a lack of information derived from ex-post studies which could provide a firm, quantitative basis for claims about the impact of infrastructure investment on regional economies and regeneration." A survey of the UK evidence (Gibbons 2017, p. 12) was still more downbeat: "Arguments for spending more in areas that are less economically successful hinge on the hope that new transport is a costeffective way to stimulate new economic activity. ... [T] he theoretical arguments and empirical evidence on this are ambiguous. Better transport may encourage local investment, but this investment is as likely to be displaced from other places within a region as it is from other regions, with no impact on large scale regional imbalances."

Caution is certainly necessary given the lack of both empirical ex post evidence and a firm theoretical account of the mechanisms through which transport infrastructure stimulates 
productivity growth. However, there are clear indications as described here that transport infrastructure investment in the UK has been skewed toward the capital; that the formal appraisal methodology has not been applied consistently to London visa-vis other regions; and - above all - that the methodology reinforces existing economic success. Combined with the theoretical limitations of CBA methodology in circumstances where there is an expectation that the path of growth might change non-marginally, we conclude there is strong justification for tilting future public investment to other parts of the UK as part of a strategic view about the geography of economic development. The publication of an industrial strategy intended to raise national productivity, in the context of the political dynamics of English city devolution and concern about the 'left behind' places, means it is now impossible to ignore the spatial consequences of infrastructure investments, as has been the case for decades now in the UK.

\section{Acknowledgements}

Our thanks to Tom Forth, Michael Kenny, Luke Raikes, Ron Martin and also to participants at the CGR-IPR Industrial Policy workshop at the University of Bath, the Industrial Policy Revisited conference of the Cambridge Political Economy Society and the Regional Studies Association conference for their comments. We are also very grateful to a number of UK officials for their constructive challenge of an earlier draft, and to the anonymous reviewers for their helpful comments. The authors are, of course, responsible for any errors or omissions.

\section{References}

Arbabi, H., Mayfield, M. \& Dabinett G. (2018). Urban performance at different boundaries in England and Wales through the settlement scaling theory. Regional Studies. DOI: 10.1080/00343404.2018.1490501

Atkins, G., Davies, N. and Kidney Bishop, T. (2017). How to value infrastructure: Improving cost benefit analysis. London: Institute for Government. Retrieved from: https://www.instituteforgovernment.org.uk/publications/value-infrastructure-september-2017

Atkinson, G., Dietz, S., Helgeson, J., Hepburn, C. and Sælen, H. (2009). Social Preferences for Risk, Inequality and Time in Discounting Climate Change. Economics Discussion Papers, No 2009-14, Kiel Institute for the World Economy. http://www.economicsejournal.org/economics/discussionpapers/2009-14

Bartolini, D., Stossberg, S. and Blöchliger H. (2016). Fiscal Decentralisation and Regional Disparities, OECD Economics Department Working Papers No. 1330. Retrieved from: http://www.oecd.org/officialdocuments/publicdisplaydocumentpdf/?cote=ECO/WKP(2016)54\& docLanguage $=$ En

Blond, P., Rosewell, B., \& Sim, D. (2016). Ticket to ride: How high speed rail for Liverpool can realise the Northern Powerhouse. London: ResPublica. Retrieved from https://www.respublica.org.uk/wp-content/uploads/2016/02/HS2-Liverpool.pdf

Bom, P. \& enny Ligthart, J. (2014). 'What Have We Learned From Three Decades of Research on the Productivity of Public Capital?, Journal of Economic Surveys, Vol. 28, No. 5 , pp. 889-916.

Burnham, A. (2017). Why England's North is still waiting for its powerhouse. The Guardian, August $22 . \quad$ Retrieved from: 
https://www.theguardian.com/commentisfree/2017/aug/22/northpowerhouse-infrastructureandy-burnham

Crescenzi. R., Di Cataldo, M. and Rodrıguez-Pose, A. (2016). 'Government Quality and the Economic Returns of Transport Infrastructure Investment In European Regions', Journal of Regional Science, Vol. 56, No. 4, pp. 555-582.

Department for Business, Energy and Industrial Strategy (BEIS). (2017). Industrial strategy: Building a Britain fit for the future. (White Paper). Retrieved from https://www.gov.uk/government/publications/industrial-strategy-building-a-britainfit-for-thefuture

Department for Transport. (2017). Strategic case supplementary guidance: Rebalancing toolkit. Retrieved from https://assets.publishing.service.gov.uk/government/uploads/system/uploads/attachment_dat a/file/669043/supplementary-guidancerebalancing-toolkit.pdf

Department for Transport. (2018). Wider economic impacts appraisal. Retrieved from https://assets.publishing.service.gov.uk/government/uploads/system/uploads/attachment_dat a/file/712878/tag-unit-a2-1-wider-impacts-overview-document.pdf

Dietz, S. and ameron Hepburn, C. (2013). 'Benefit Cost Analysis of non-marginal climate and energy projects', Energy Economics, 40, 61-71.

Donaldson, D. (2018). 'Railroads of the Raj: Estimating the Impact of Transportation Infrastructure', American Economic Review, 108(4-5), 899-934.

Eddington, R. (2006). The Eddington Transport Study, (December) Retrieved from: http://webarchive.nationalarchives.gov.uk/20080804142919/http://www.dft.gov.uk/about/strate gy/transportstrategy/eddingtonstudy/

Flyvbjerg, B. (2014). 'What You Should Know about Megaprojects and Why: An Overview,' Project Management Journal, vol. 45, no. 2, pp. 6-19.

Forth, T. (2017). 'Investment is Political'. Retrieved from: https://www.tomforth.co.uk/investmentispolitical/

Gibbons, S, (2017). "Planes, Trains and Automobiles: The Economic Impact of Transport Infrastructure," SERC Policy Paper 13, http://www.spatialeconomics.ac.uk/textonly/serc/publications/download/sercpp013.pdf

Gibbons, S., Heblich, S. and Pinchbeck, E. (2018). "The Spatial Impacts of a Massive Rail Disinvestment Program: The Beeching Axe", LSE CEP Discussion Paper 1563, http://cep.Ise.ac.uk/pubs/download/dp1563.pdf

Graham, D. and Van Dender, K. (2011). "Estimating the agglomeration benefits of transport investments: some tests for stability", Transportation, 38: 409-26.

Greater Manchester Combined Authority, (2014). Association of Greater Manchester Authorities, Greater Manchester Local Enterprise Partnership and Transport for Greater Manchester Greater Manchester Growth and Reform Plan: Transport Strategy and Investment Plan, http://www.tfgm.com/ltp3/Documents/GMGRP-Transport-Strategy.pdf

HM Treasury. (2007). The green book. Retrieved from https://webarchive.nationalarchives.gov.uk/20080305121602/http://www.hm-

treasury.gov.uk/media/3/F/green_book_260907.pdf

HM Treasury. (2011). The green book. July 2011 revision to 2003 version. No longer available online.

HM Treasury. (2017). Public expenditure statistics analysis 2017. Retrieved from https://www.gov.uk/government/statistics/public-expenditure-statistical-analyses-2017.

HM Treasury. (2018). The green book. Retrieved from https://assets.publishing.service.gov.uk/government/uploads/system/uploads/attachment_dat a/file/685903/The_Green_Book.pdf

HM Treasury \& Infrastructure and Projects Authority (2017). National Infrastructure and $\begin{array}{llll}\text { Construction } & \text { Pipeline } & \text { Spreadsheet, } & \text { Autumn }\end{array}$ 
https://www.gov.uk/government/publications/national-infrastructure-and-construction-pipeline$\underline{2017}$

iBUILD (2018). Closing the Gap: local infrastructure business models to support inclusive growth, (iBUILD Research Centre Final Report). Newcastle: Newcastle University. Retrieved from: http://research.ncl.ac.uk/ibuild/2018finalreport/

Industrial Strategy Commission (2017). The Final Report of the Industrial Strategy Commission Retrieved from: http://industrialstrategycommission.org.uk/2017/11/01/the-finalreport-of-the-industrial-strategy-commission/

Laird J.J., Nash C. \& Mackie, P.J. (2014). 'Transformational transport infrastructure: cost benefit analysis challenges', Town Planning Review, vol. 85, no. 6, pp. 709-30, http://eprints.whiterose.ac.uk/87446/

Little, I.M.D. and.Mirrlees, J.A (1974). Project Appraisal and Planning for Developing Countries. New York: Heinemann.

McCann, P. (2016). The UK regional-national economic problem: Geography, globalisation and governance. London: Routledge.

Merton, R. K. (1968). "The Matthew Effect in Science," Science, 5 January 1968, 159(3810): 56-63.

Metz, D. (2016). Travel Fast or Smart? A Manifesto for an Intelligent Transport Policy. London London: Publishing Partnership.

National Audit Office (2017). Update on the Thameslink Programme. Retrieved from: https://www.nao.org.uk/wp-content/uploads/2017/11/Update-on-the-Thameslinkprogramme.pdf

National Audit Office (2018). Investigation into the Department for Transport's decision to cancel three rail electrification projects. Retrieved from: https://www.nao.org.uk/report/investigation-into-the-department-for-transports-decision-tocancel-three-rail-electrification-projects/

Office for National Statistics (ONS). (2018a). Nominal and real regional gross value added (balanced) by industry. Retrieved https://www.ons.gov.uk/economy/grossvalueaddedgva/datasets/nominalandrealregionalgross valueaddedbalancedbyindustry

Office for National Statistics (ONS). (2018b). Labour productivity: Region by industry. Retrieved from https://www.ons.gov.uk/economy/economicoutputandproductivity/productivitymeasures/datas ets/industrybyregionlabourproductivity

Organisation for Economic Co-operation and Development (OECD). (2002). The impact of transport infrastructure investment on regional development. Retrieved from https://www.itfoecd.org/sites/default/files/docs/02rtrinveste.pdf

Organisation for Economic Co-operation and Development (OECD). (2018). Strategic investment packages. Retrieved from https://www.itfoecd.org/sites/default/files/docs/strategic_investment_packages.pdf

Pisu, M., Pels, B., \& Bottini, N. (2015). Improving infrastructure in the United Kingdom (OECD Economic Working Papers No. 1244). Paris: Organisation for Economic Co-operation and Development (OECD). Retrieved from http://www.oecd.org/officialdocuments/publicdisplaydocumentpdf/?cote=ECO/WKP(2015)62\& docLanguage $1 / 4$ En

Preston, J. (2012). Integration for seamless transport (ITF Discussion Paper No. 1). Paris: Organisation for Economic Co-operation and Development (OECD). Retrieved from http://www.internationaltransportforum.org/itrc/DiscussionPapers/DP201201.pdf

Raikes, L. (2018). Future transport investment in the North: A briefing on the government's new regional analysis of the national infrastructure and construction pipeline (IPPR North Report). Retrieved from https://www.ippr.org/publications/future-transportinvestment-in-thenorth-briefing 
Rodríguez-Pose, A. (2018). The revenge of the places that don't matter (and what to do about it). Cambridge Journal of Regions, Economy and Society, 11(1), 189-209.

Sen, A., Stiglitz, J., \& Fitoussi, J.-P. (2009). Report by the Commission on the Measurement of Economic Performance and Social Progress. Retrieved from https://ec.europa.eu/eurostat/documents/118025/118123/Fitoussi+Commission+report

Sensier, M., \& Devine, F. (2019). Assessing regional economic resilience for the implementation of local industrial strategies (Working Paper). Manchester: University of Manchester.

Stewart, J. (2013). Give the economic benefits of infrastructure a chance to breathe. The Guardian, February 11. Retrieved from www.theguardian.com/publicleadersnetwork/2013/feb/11/economic-benefits-infrastructure-greater-manchester

Transport for London. (2015). Crossrail 2: Regional and national benefits. Retrieved from https://consultations.tfl.gov.uk/crossrail2/october2015/user_uploads/g8.pdf

Transport Select Committee. (2018). Rail infrastructure investment. London: House of Commons. Retrieved from

https://publications.parliament.uk/pa/cm201719/cmselect/cmtrans/582/58202.htm 